\title{
Business Records from Mexico City
}

Somewhat over a year ago the Society received, through the kindness of Mr. Charles P. Howland, Director of Research, Council of Foreign Relations, New York City, a fine collection of Mexican manuscripts. The material falls into two distinct groups - I I3 volumes, the records of Alfred and Andres Lefebvre, who were engaged in both retail and wholesale trade in Mexico City, and 27 volumes, the records of the Hacienda de San Bartolomé del Monte, Provincia de Tlaxcala, Mexico, which was owned by Don Manuel Fernandez del Castillo y de Mier. This article will concern the records of Alfred and Andres Lefebvre, which cover the years I 8631900.

Alfred Lefebvre was, during his early career, a wholesale and retail merchant in Paris. He was apparently a man of both ambition and intelligence. What drew him to Mexico City to establish a branch of the Paris firm is not certain. Was it because of family connections there which offered an opening to him; did he see in a new country unusual opportunity; or was it that the political situation arising out of the French intervention in Mexico and Maximilian's accession to the throne made him think the French might be favored there? These are three possibilities - perhaps all played a part. The records do not indicate at just what date Alfred Lefebvre arrived in Mexico, but they do show that he was certainly there in 1863 . It is possible that he was at first associated in business with S. Savary, who was apparently his brother-in-law, and who conducted a store in Mexico City under the firm name "S. Savary et Daume." However, it could not have been long before Lefebvre had established himself as an independent merchant.

His business was diversified in the services which he performed. He was, first of all, a wholesale and retail merchant, supplying his customers with nearly every possible need. He conducted import and export trade of considerable volume with houses in Paris, Le Havre, Nantes, Zurich, Hamburg, Strassburg, London, Manchester, Glasgow, New York, Philadelphia, Chicago, and San Francisco. The list of imports was as varied as the list of commodities handled in his stores. The exports consisted chiefly of maize, jalap, vanilla, tobacco, quitch-grass, furs and caoutchouc. It also appears that he performed some of the functions of a banker; he maintained open accounts for numerous individuals, some of whom were not even 
the regular customers. They sent him money to be deposited to their accounts, and sent orders for payments, similar to checks, to be charged against those accounts. Further, he was a manufacturer. He established a factory for the making of parasols, sunshades, and umbrellas, which he sold through his own stores as well as through other dealers. Finally it seems clear from the records that Lefebvre continued to maintain his store in Paris. There are frequent references to the "Maison de Paris" in contrast with the "Maison de Mexique." His representatives in Paris wrote by every mail to inform Lefebvre concerning all details in the conduct of the business there.

Returning to a further discussion of the wholesale and retail enterprise in Mexico City, it is interesting to note some of the outstanding characteristics of his business policy. Price lists indicate that the firm did not quote the same prices to all customers. All sales on credit had to be secured by promissory notes signed by the purchaser, and shipments were not made unless the note was first registered in Lefebvre's books.

The credit situation in general was poor. R. G. Dunn furnished Lefebvre with periodical information about the standing of customers. Some of these letters are rather amusing. In one, half a page is devoted to a statement that a certain customer is a good credit risk, but a footnote says that he killed someone and the police are looking for him. Lefebvre often asked his agents for information concerning the health of various customers, always reminding the agent that, in case of the illness of the customer, the customer's merchandise, not yet paid for, should be seized at once. An interest rate of $12 \%$ was charged against sales on credit and $24 \%$ interest on bills due but not paid. One policy followed by Lefebvre was that of sending his clerks to competing stores to ascertain quality and price of merchandise - the modern system of comparative shopping. In one letter Lefebvre reveals something of his knowledge of business psychology. He instructs his purchasing agent to purchase goods from the Indians in units of dozens rather than pounds, for he says, "The Indians feel that the dozen is a much more just measurement of what they bring to sell."

Perhaps the greatest obstacle to business progress was the lack of banking facilities. For the most part, there was no reliance on shifting of credic to balance transfer of goods. Actual money (gold and silver) passed from hand to hand and was transported to distant parts of the country for purchase of goods. This was a costly 
means of payment due partly to high rate of risk and to the slowness with which transactions were made. For some time there were no reputable express companies in Mexico and it was necessary to rely on trustworthy individuals to transport the gold from place to place. For this reason the entrance of the Wells Fargo Company into Mexico was greatly welcomed and the success of the company was almost immediate.

Lefebvre's business grew rapidly. By 1880 he had at least five permanent stores scattered throughout Mexico City. In addition to these stores he opened booths in the public markets whenever some festivity was to take place in the city. These were only opened for a limited number of days and for only four or five hours a day. It was several times suggested to Lefebvre that he open branches of his store in other cities, but this he was determined not to do, because of difficulties of management and control. His stores in Mexico City, however, handled a volume of merchandise so great that he finally installed an elevator to facilitate the handling of goods.

Lefebvre's son Andres was born in Paris and received his education partly in France and partly in Mexico. He spoke French, Spanish, and English readily, and in general appears to have had an excellent education. At eighteen he entered his father's business and was soon taking complete responsibility in Mexico whenever his father went to Paris to attend to the business there. Eventually he took over the entire management of the business. Andres married the daughter of Don Manuel Fernandez del Castillo y de Mier, a member of one of the most distinguished families of Mexico. Through his wife, he inherited the Hacienda de San Bartolomé del Monte. The records of this hacienda comprise the second part of this collection of Mexican manuscripts and will furnish the subject of a brief article in the June Bulletin. 